\title{
The Standing Conference of Canadian Organizations Concerned for Refugees: Montreal, November 22/24, 1984
}

Better attended. Better organized. But many of the same themes. After the opening evening session in which - the government announced its planned increase in its target for sponsored refugees by $10 \%$ - which was favourably received - the conference zeroed in on the overal global perspective on refugees.

John Contier, of the Catholic Relief Services in the U.S.A., addressed the conference on the cituation of Salvadorean, Guatemalan, and Nicaraguan - both Ladino and Miskito - refugees in Honduras. He noted, that unlike the 3,000 or so Nicuaraguan Ladino refugees who are unrestricted in their movements and the 18,000-21,000 Nicaraguan Miskito Indians who have been relocated to interior Miskito areas of Honduras, the large numbers of Guatemalan and Salvadorean refugees are kept in camps which are under the control of the military. When, after his talk, he was asked a question about security for the Guatemalan refugees, in particular about a refugee who was killed by the Honduran military authorities, John Contier explained that the incident in question was an accident where a Honduran soldier's gun went off when he was boarding a truck, since that incident was not isolated, an investigation would be appropriate.

In his talk, Contier emphasized three points about the Salvadorean and Guatemalan refugees in Honduras. First, they don't want to be relocated further into the interior in Honduras. Secondly, there was general scepticism about the 'voluntary' repatriation program supported by the U.S., since the security guarantees and the opportunity to be gainfully employed upon return were in doubt. Finally, though these refugees lack freedom of movement, the co-ordinated work of the NGOs in Honduras was invaluable in providing support - material and moral - for the refugees.

Giovanni Fiorino (Centre de services sociaux, Montreal) spoke of the Bangladeshi refugee claimants $(90 \%$ in Montreal) and the situation back in Bangladesh. In 1982 only 50 Bangladeshis ar- rived in Montreal and made claims for refugee status. In 1983, September, 700-800 Bangladeshis had arrived to claim refugee status. Their situation only became publicized when they went on a hunger strike. It is estimated that one third of the claimants have been successful. Of the majority who have been refused, some are already under deportation order.

Fiorino stressed how ignorant Canadians were of the situation in Bangladesh in comparison to Chile as an example. He claimed that Bangladesh has been in a virtual continuous stage of seige since 1974. Over 25,000 (he admitted the figure was disputable political assassinations or disappearances of 28 to 35 year olds have taken place. He vividly described scenes of rape, torture, murder, burial alive, dismemberment, and other violent and unseemly acts. What was needed, he insisted, was an independent investigation of the situation in Bangladesh by human rights organizations in Canada to provide a source of information that went beyond the reports of Amnesty International. In the meanwhile, deportation proceedings against the Bangladeshis should be suspended. The imposition of a visa requirement for Bangladeshis was viewed as discriminatory in preventing them from seeking the protection of Canada.

\section{Annual Review and \\ Consultation \\ Kirk Bell announced that this year's annual review would be more comprehensive and would start earlier, in January rather than April.}

In place of Karl Stumpf from Hong Kong, Lloyd Jones of Thunder Bay reported on the new situation in the closed camps for Vietnamese retugees and the Migration Services Department's program to help sponsors in Canada finance the resettlement of these refugees, a program particularly. aimed at Canada as one of the tew countries with a private sponsorship program which can augment government quotas.
Joyce Yedid, a lawyer from Montr addressed the conference on the him ical background of the 3,000 or so Lankan Tamils who have applied refugee status in Canada. Joyce $Y$ stressed that the overwhelming num of these made their claims after communal violence of 1983, viole which has recurred with regule. since then. She noted that 25-30 the claimants had been accepted. that deportation orders are being cessed for individuals nearing the of the claims process - though admitted that none of the deporta. orders had as yet been enforced. argued that there should be a stay deportation proceedings and those already here should have it status regularized with permanent dence granted for those who demonstrated that they had been cessfully established. Others would given 6 months to demonstrate they could establish themselves adjust to Canada.

Barbara Jackman, a Toronto lawy ended her talk with an analysis of terrible political and questionable le situation in Chile; she began wits very moving account of her last ree visit to Chile which demonstrated vividly the increased repression in country. On the first night of her $v$ to a community clinic in a poor ne: bourhood, she personally witnessed death of a young boy who had $b$ shot in the back of the head at while walking home. She spent the ond night on the floor of a pri house as soldiers shot at random in streets; she has her first grey huirs momento of that night. At a sut quent visit of 300 to the grave Allende, six buses of military met the peaceful demonstrators as left the cemetery, forced them into the cemetery and shot and gased them without provocation. de tacto state of seige of the poor bourhoods has since become a de one. The repression has increased become more systematic.

Ot tive main human rights orga tions in Chile, only one, Vicariat the Catholic Church, has a wor relationship with the Canadian 
bassy, though it was not the same quality as that with France, Sweden and Switzerland. Fasic (the Protestant church organization), Jackman reported, had a negative relationship, and the other human rights organizations thought that the relationship was not worth the time. Canada was rated just above the American and British embassies, and well below that of other European embassies with respect to a concern for human rights.

Juan Iteriago spoke on the problem of the Peruvians in Montreal and the increasing restrictive policy in Canada tuwards Peruvian refugee claimants, explained partially, he said, because Canada does not recognize that Peru is a quasi-democracy because repression and disappearances occurred as in El Salvador but not as extensively as in Argentina.

Iteriago (supported by some other lawyers at the conference) argued that the confidentiality of the claimant was not respected. Pressure at the entry point induced individuals to make declarations that they did not want to make signing documents which permitted the Canadian authorities to contact the local police back home to make inquiries about the refugee. During the session, these charges were clearly and unequivocally denied by representatives of both the Immigratio and the External Affairs Departments in Canada. They claimed that the forms refugee claimants sign allowed the authorities to undertake any necessary medical treatment, and, any criminal records only prior to their being granted landed immigrant status, and was not utilized while the refugee was proceeding through the claims process. It could not be used in any way to jeopardize that claim. Contacts were made with Interpol but not with the local police authorities and Interpol files are kept independently of any national police.

Iteriago claimed that Salvadorean claimants were being sent back to the U.S.A., and the U.S. in turn sent them back to El Salvador. Raf Girard insisted $+$

at the only returnees to the U.S. would be those who a) had permanent residence in the United States; and b) those for whom guarantees had been received that they would not be sent back to El Salvador.
Iteriago asked that the 'democratic' status of Peru be investigated, that the claims currently in process be reviewed in light of this information, that the suffering of the claimants in Canada be relieved, that a special program be offered for Peruvians, that special measures which he claimed were applied to Peruvian claimants be stopped, and that the visa requirement for Peruvians be removed. In light of the clear and unequivocal denial of some of the claims, the credibility of the whole presentation was weakened.

Raf Girard then reported on the results of the UNHCR Executive Committee (40 countries plus Namibia that oversaw the programs of the UNHCR on behalf of the UN). He summarized 12 days of proceedings dealing with aid and development, protection, durable solutions, etc. He noted that Ex. Comm. (the Executive Committee) proceeded by consensus, making it difficult to table hard hitting resolutions. On the other hand, the bitter block voting and factions of other UN bodies was avoided. No single issue dominated the 1984 Ex. Comm. meetings, perhaps because there was no new large scale exodus demanding world attention. Nevertheless, it was difficult to maintain optimism since there had been erosion in non-refoulement, beginning with the commitment to resettle refugees, and only very slow progress in the word towards durable solutions.

\section{The Supreme Court}

The Supreme Court was expected to announce its decision on the key question of whether our Constitution obligated Canada to provide oral hearings for refugee claimants. The announcement of the decision has evidently been postponed unitil January. Does this indicate that the court will require oral hearings and is merely allowing time for the department to deal with all those claimants who did not receive oral hearings?

Canada was particularly concerned with resettlement and protection. Holland, Germany and Sweden focused on the spontaneous migrants who were looking to better their lot and not seeking protection. These spontaneous migrants interfered with a country's ability to handle legitimate refugees seeking protection. A study of these spontaneous migrants was to be initiated.

Canada viewed refugee resettlement as an orphaned durable solution without advance planning. The High Commission was requested to use the annual plan of Canada as a systematic framework for all countries participating in resettlement. Overall planning could then be undertaken in this area.

In the protection debate, the pessimistic attitude of the High Commissioner in his introductory remarks was reinforced. Military attacks on retuget' camps, rescues at sea and travel documents for refugees were ail discussed. Little progress was made on the first issue, particularly because it had political overtones, and UNHCR operated by consensus. Rescues at sea were supported in principle because the rescues had diminished from $20 \%$ to $7 \%$. Incentives had to be provided to ship masters and the countries whose flags they flew. In practice, however, Canada did not make a specific commitment to RASRO (The Rescue at Sea Relief Operation). Canada, however, had initiated preliminary discussions with countries with large naval fleets, such as Greece, to attempt to work out a practical formula. These discussions are in progress. The debate on travel documents was uneventful, Girard reported.

Anton Yurkevich of External Affairs reported on other overseas programs of the High Commission, particularly those with which Canada had a concern. He described Canada's involvement in the aid program - Canada donated almost \$13 million dollars, and was the fifth largest contributor. Yet Canada feared creating dependency on the part of the refugees. Canada, therefore, supported attempts to integrate refugees into development programs. Afghanistan was cited as an example. In another instance, $\$ 1.700,000$ was pledged at ICARA II to tacilitate integration programs.

Canada took a very clear itand supporting the High Commissions etfort. to co-ordinate its programs with other UN agencies without diminishing the special programs needed for retugees. 